\title{
Northeastern extension of Neogene magmatism in Africa: Evidence from the Zitouna rhyolite, Algeria
}

\section{Extensión nororiental del magmatismo Neógeno en África: evidencia de la riolita de Zitouna, Argelia}

\author{
Menana Daif ${ }^{1} \&$ Abderrahmane Toubal ${ }^{2}$ \\ ${ }^{1}$ Badji Mokhtar-Annaba University, Laboratory of LGRN, P.O. Box 12, 23000 Annaba, Algeria \\ (e-mail: daifmenana@yahoo.fr) \\ ${ }^{2}$ Badji Mokhtar-Annaba University, Laboratory of Geology, P.O. Box 12, 23000 Annaba, Algeria.
}

(e-mail: toubim@yahoo.fr)

\begin{abstract}
The Zitouna rhyolite is the easternmost representative of the Neogene magmatism in the Northeast of Algeria. It is composed of two intrusive rhyolitic apexes: the first outcrop is poorly known and not dated; the second one is greater, and not previously described. It is a well-differentiated rock that does not exceed $12 \mathrm{Ma}$ (Post-Serravallian). Geochemical data show that it belongs to $\mathrm{S}$-type granites with a high peraluminous character corroborating a crustal protolith. The Zitouna rhyolite is considered as the continuation of other neighbouring magmatic episodes and can be related to the late Neogene tectono-magmatic evolution of northeast Africa.
\end{abstract}

Keywords: rhyolite, post-Serravallian, S-type granites, peraluminous, Zitouna, Algeria.

Resumen: La riolita de Zitouna es la representación más oriental del magmatismo neógeno en el noreste de Argelia. Está formada por dos cuerpos intrusivos riolíticos: el primer afloramiento es vagamente conocido y no ha sido datado; el segundo es de mayores dimensiones y no ha sido descrito previamente. Se trata de una roca bien diferenciada que no excede de los $12 \mathrm{Ma}$ (Post-Serravaliense). Los datos geoquímicos muestran que corresponde a un granito de tipo $\mathrm{S}$ con alto carácter peralumínico, lo que corrobora un protolito cortical. La riolita de Zitouna es considerada como la continuación de otros episodios magmáticos vecinos y puede ser relacionada con la evolución tectono-magmática del noreste africano durante el Neógeno superior.

Palabras clave: riolita, post-Serravaliense, granitos de tipo S; peralumínico, Zitouna, Argelia. 
Zitouna (former Toustain) is a locali+ty situated at about $80 \mathrm{~km}$ to the southwest of Annaba, northeast Algeria. It belongs to the eastern part of the Maghrebides (Fig. 1). The first rhyolitic rock recorded at Zitouna is an outcrop of 65 meters length appearing in the middle of Quaternary debris. Since its relationships with the enclosing rocks are not visible, its relative age remains unknown (Hilly and Rast, 1954; Vila 1980). At about $2 \mathrm{~km}$ to the west of the same region there is a second outcrop measuring 600 meters length and never reported before.

In spite of their different size and location, the two rhyolite bodies are identical in appearance and both on the mineralogical and geochemical composition. Apart from a short petrographic description of the first outcrop (Hilly and Rast, 1954), the Zitouna rhyolite remained undescribed and almost unknown until the present study. The purpose of this study is to determine petrographic and geochemical characteristics of this rhyolite, as well as its age, using new observations and new analyses.

\section{Geological setting}

Northern Algeria is part of the Alpine chain of Maghrebides resulting from the geodynamic evolution of the Tethys (e. g., Durand-Delga, 1980; Bouillin, 1986). It includes different tectono-stratigraphic zones, which from north to south are: 1) the internal zones, i.e., the Alkapeca (Alboran-Peloritani-Calabria) or meso-Mediterranean area, representing several microplates of European origin; 2) the flysch area that corresponds to the sedimentary cover of the ancient Tethys; and 3) the external zones (Tell-Rif) related to the African paleomargin.

The Zitouna region is part of the eastern Alpine chain of northern Algeria and is related to the southern part of the internal zones (Vila, 1980). The flysch area is mainly represented by a thick terrigenous detrital formation of Lower Oligo-Miocene age: the Numidian Flysch. This succession is affected by a Tertiary active geodynamic event attested by several tectonic phases and is intruded by a Neogene polycyclic magmatism that has been the subject to sever-

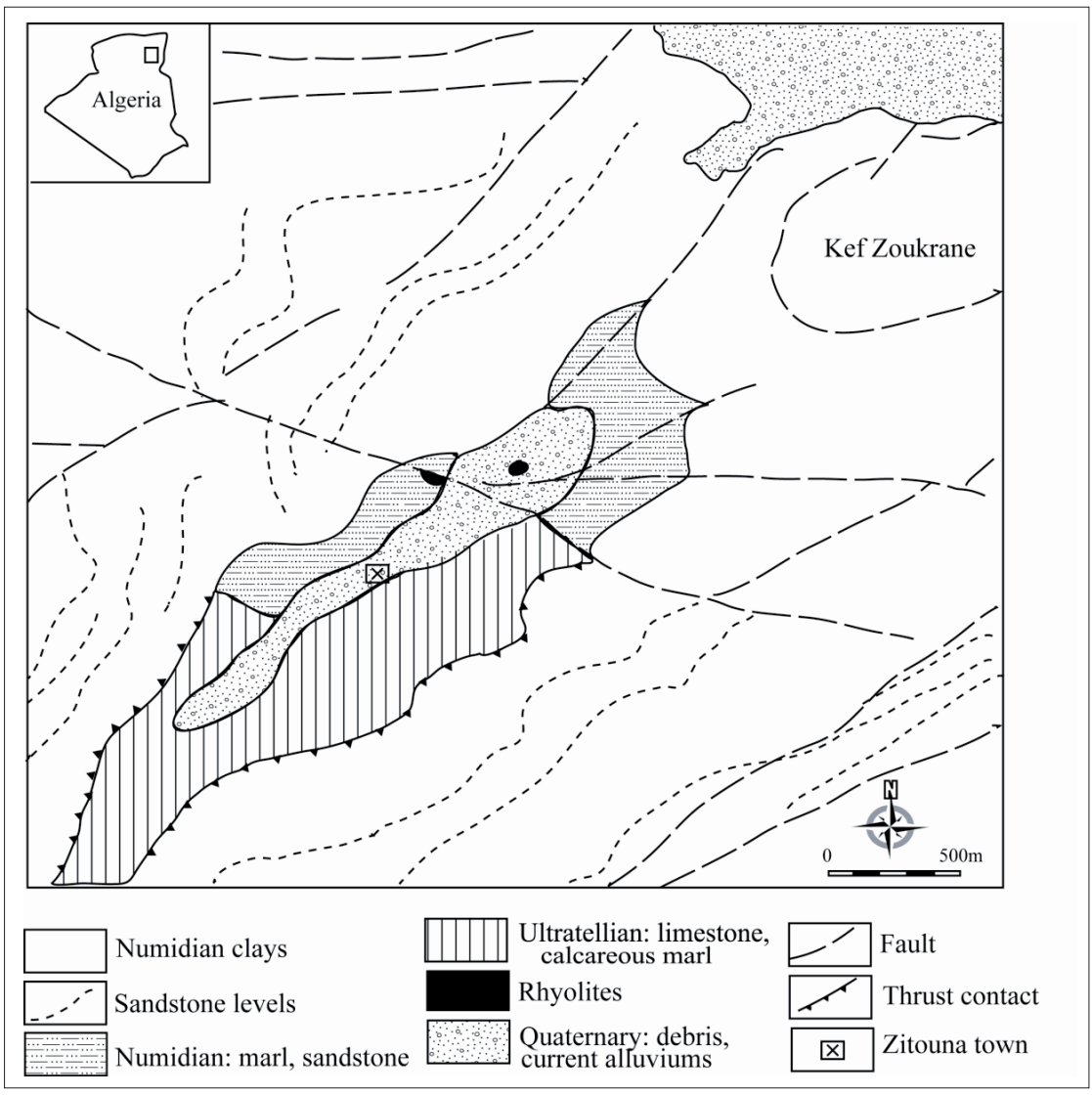

Figure 1. Simplified geological map of the Zitouna area with location of this region within Algeria. 
al studies (e. g., Raoult, 1974; Vila, 1980). Most igneous rocks of northeast Algeria display calc-alkaline affinities and their radiometric ages range from 20 to $8 \mathrm{Ma}$ (Hilly, 1962; Bellon, 1976; Fougnot, 1990; Maury et al., 2000; Laouar et al., 2005).

In the region of Zitouna, two major structural units are represented: the ultratellian series composed of Upper Cretaceous calcareous marls, and the $\mathrm{Nu}-$ midian flysch formed by alternations of sandstones and marls of Oligo-Miocene age. These two units correspond to different thrust sheets. The Numidian sheet is located in the uppermost position, whereas the ultratellian nappe appears as a tectonic window. The whole package is locally intruded by some igneous rocks. Superficial deposits consist of river alluvium, scree slopes and hydrothermal travertine.

Apart from their Neogene age, other important geological features are common to all igneous rocks of northeast Algerian area: they often intrude different flysch series (Mauretanian, Massylian and Numidian) and are interpreted to be associated with relative motion between the African and European plates generating mantle-crust interaction phenomena. However, different authors reported evidence of an older magmatism such as siliceous limestones and silexites interbedded in the Eocene Mauretanian flysch of Grande Kabylie and the North Constantine (Gélard, 1969; Raoult, 1974).

\section{Age of the rhyolites}

Some field observations allow unravelling the age of the Zitouna rhyolite (Fig. 2A). The second apex is intruded within the Numidian flysch. The host rocks (marl belonging to the flysch succession) have undergone a contact metamorphism beside the second apex. This indicates that these intrusions are post Numidian nappe-setting, and therefore, the studied rocks do not exceed $12 \mathrm{Ma}$ (post-Serravallian). In addition, the sedimentary xenoliths collected clearly belong to Numidian sandstone and argillite (Langhian to Early Tortonian) (Fig. 2B). At about $80 \mathrm{~km}$ further east, similar igneous rocks from Nefza (northwest Tunisia) crop out. These rocks intruded the Numidian flysch and supplied K-Ar ages ranging between 12 and $8 \mathrm{Ma}$ (Bagdazarjan et al., 1972). All these relations between the rhyolites and the host rocks point out that the Zitouna rhyolite would be related to the Neogene magmatism.

\section{Rhyolite analyses}

Four representative samples of rhyolite were selected in the field for the petrographic and geochemical investigation. In order to carry out a comparative study we have also sampled and analysed two
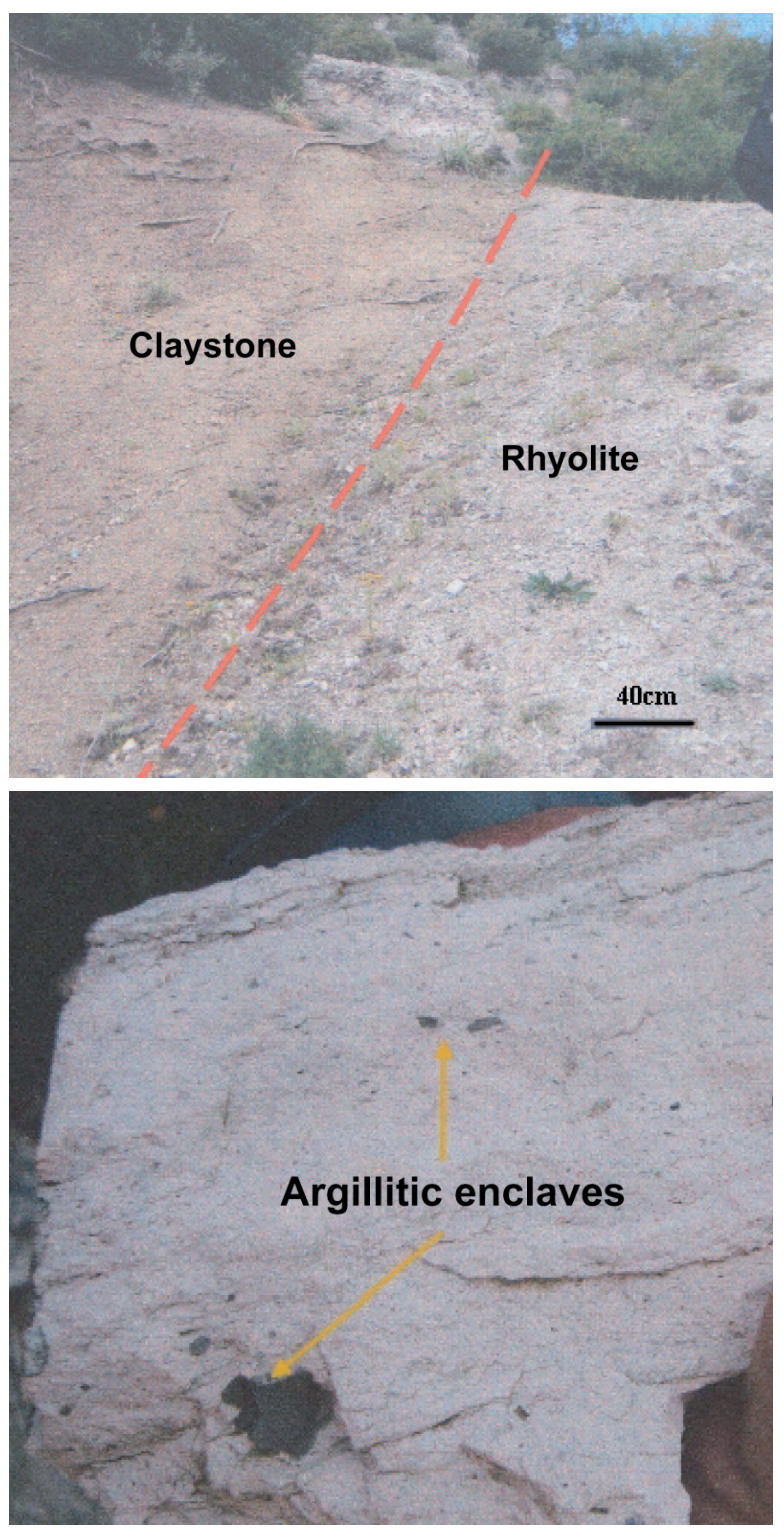

Figure 2. A) Geological contact (shown with a dashed line) between the Zitouna rhyolite and a claystone of the Numidian Flysch, and B) rhyolite sample from the western outcrop of $\mathrm{Zi}$ touna showing sedimentary xenoliths. 
rhyolites from Chetaibi and one from Ain Barbar (Northwest of Annaba, in northeast Algeria).

In the seven samples, 36 major and trace elements have been analysed. Major elements were determined by wavelength-dispersive X-ray fluorescence (XRF) spectrometry using fused lithium-tetraborate discs. Pressed powder pellets were used for trace element determinations by XRF. All XRF analyses were made with a Phillips PW-2400 spectrometer at the GeoForschungsZentrum (GFZ) in Potsdam, Germany. The rare earth elements (REE) Ba, Rb, $\mathrm{Sr}, \mathrm{V}, \mathrm{Y}, \mathrm{Zn}, \mathrm{Zr}, \mathrm{Ga}, \mathrm{Nb}, \mathrm{Cr}$ and $\mathrm{Ni}$, were analysed by inductively coupled plasma-mass-spectrometry (ICP-MS) with a Perkin-Elmer/Sciex Elan Model 500 ICP mass- spectrometer using the methodology outlined by Dulski (1994). The analyses were carried by inductively coupled plasma-optical emission spectrometer (ICP-OES, Vista MPX) at the GFZ. Sample preparation involved $\mathrm{Na}_{2} \mathrm{O}_{2}$ standard fusion and dilution techniques for dissolving rock powders. Analytical precision was checked against international reference standards.

\section{Petrography}

The Zitouna rhyolite crops out as two elliptical domes and shows a variation in terms of colour. It is very fine grained and varies from grey to white with some darker bands (Fig. 2B). It contains sedimentary fragments of variable size $(1-20 \mathrm{~cm})$ broken off from the intruded Numidian sandstone. In some places large phenocrysts of orthoclase are clearly visible to the naked eye. The groundmass is partially devitrified by subsequent recrystallization masking the primary textures (Fig. 3). This devitrification radiates from many points of the rock where tiny new crystals form curved bundles giving rise to spherulites. The main texture is slightly fluidal with some large phenocrysts. The mineral paragenesis is characterized by euhedral to subhedral phenocrysts of corroded quartz, alkali feldspar, plagioclase $\left(\mathrm{An}_{5}\right.$. ${ }_{15}$ ) and biotite with zircon inclusions (Fig. 3A). It also contains a certain amount of minerals resulting from alteration: chlorite, sericite, epidote and calcite. The Zitouna region is characterized by the lack of any other igneous rocks (intermediate or mafic) in its vicinity.
The rhyolite from Ain Barbar is a massive, white rock with columnar jointing; it is surrounded by gneisses and micaschists of the Edough basement. A microscopic study reveals many embayed quartz phenocrysts, some plagioclases $\left(\mathrm{An}_{15-25 \%}\right)$, altered alkali feldspar and rare biotites with apatite inclusions
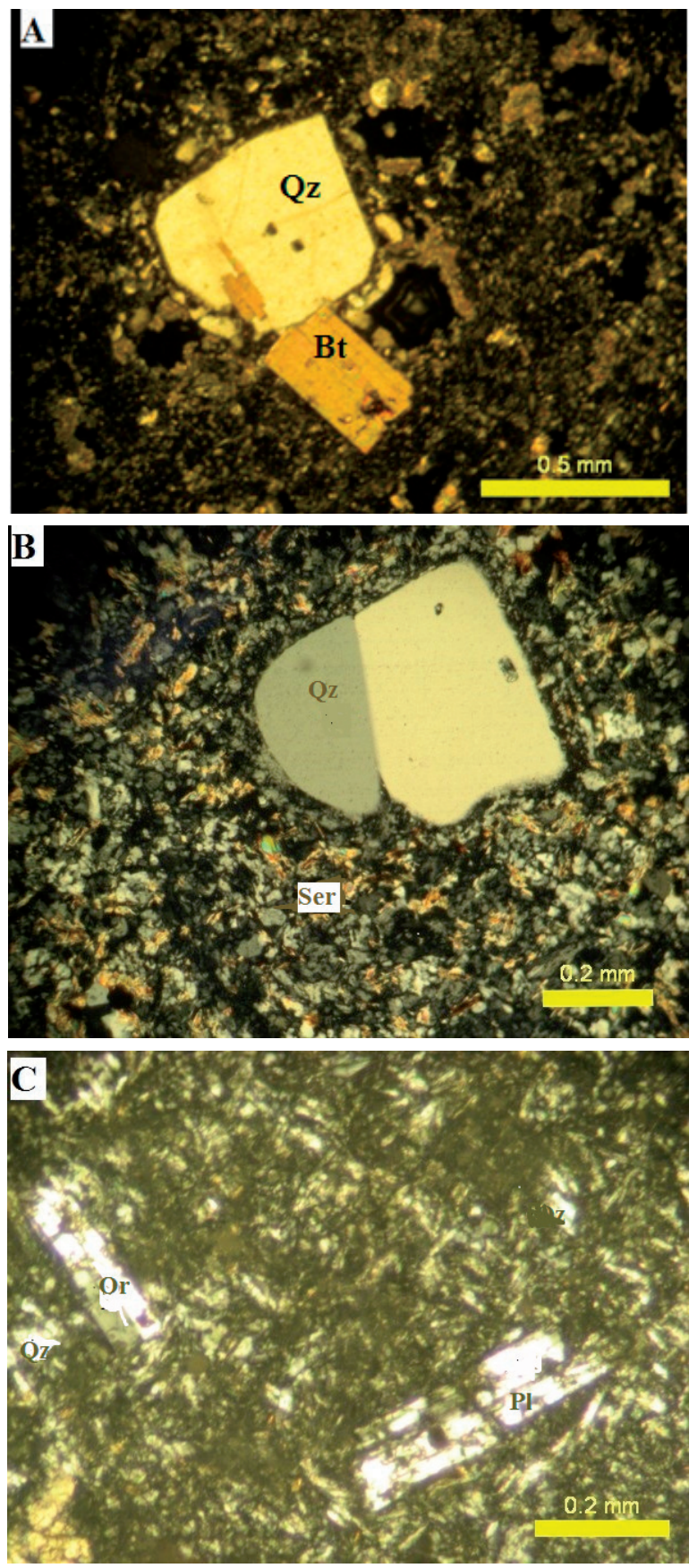

Figure 3. Representative thin sections of the studied rhyolites from Zitouna (A), Ain Barbar (B) and Chetaibi (C): quartz $(\mathrm{Qz})$, biotite $(\mathrm{Bt})$, plagioclase $(\mathrm{Pl})$, orthoclase $(\mathrm{Or})$ and sericite (Ser). Crossed polarized light. 
(Fig. 3B). The felsitic matrix is rich in sericite. This rhyolite is associated with microgranites of the same age, i.e., $16 \mathrm{Ma}$ (Marignac, 1985). This region is affected by hydrothermal alteration and shows polymetallic mineralizations.

The Chetaibi rhyolite sample comes from a lava flow interbedded in Miocene marls. It is a massive, light green rock with some small vesicles and few minerals visible to the naked eye. A microscopic observation reveals the occurrence of plagioclase $\left(\mathrm{An}_{20-35}\right)$, orthoclase, some anhedral quartz and rare biotites with zircon inclusions (Fig. 3C). The matrix is felsitic and partly devitrified. This rhyolite is associated with other acidic, intermediate and basic rocks: microgranites, andesites, diorites and gabbros whose age is $15-16 \mathrm{Ma}$ (Bellon, 1976).

\section{Geochemistry}

The results of the chemical analyses carried out for major and trace elements are listed in Table I. When compared to average values given by Le Maitre (1989), the bulk-rock concentrations of the Zitouna rhyolite are characterized by a higher proportion of $\mathrm{SiO}_{2}(71.60 \%-77.90 \%)$, and $\mathrm{K}_{2} \mathrm{O}(3.78 \%-4.68 \%)$, and lower percentages of $\mathrm{CaO}(0.36 \%-0.54 \%)$, $\mathrm{Na}_{2} \mathrm{O}(1.01 \%-2.50 \%), \mathrm{FeO}_{t}(0.68 \%-1.48 \%)$, and $\mathrm{TiO}_{2}(0.06 \%-0.11 \%)$. The low $\mathrm{FeO}_{\mathrm{t}}$ contents (less than $1.48 \%$ ) are correlated to the limited amount of ferromagnesian minerals. $\mathrm{TiO}_{2}$ has a similar behaviour. The Chetaibi rhyolite exhibits higher values of $\mathrm{CaO}(0.74 \%-0.89 \%)$ and very lower $\mathrm{P}_{2} \mathrm{O}_{5}(0.02 \%-$ $0.03 \%)$. The Ain Barbar rhyolite has a very high proportion of $\mathrm{K}_{2} \mathrm{O}(9.37 \%)$ and lower $\mathrm{Na}_{2} \mathrm{O}(0.06 \%)$.

\begin{tabular}{|c|c|c|c|c|c|c|c|}
\hline & \multicolumn{4}{|c|}{ Zitouna } & \multicolumn{2}{|c|}{ Chetaibi } & Ain barbar \\
\hline wt \% & $\mathrm{RZ1}$ & $\mathrm{RZ2}$ & RZ3 & RZ4 & $\mathrm{C} 21$ & $\mathrm{C} 24$ & $\mathrm{AB} 11$ \\
\hline$\overline{\mathrm{SiO} 2}$ & 71.60 & 72.40 & 77.90 & 72.90 & 76.10 & 79.80 & 74.00 \\
\hline TiO2 & 0.11 & 0.06 & 0.06 & 0.06 & 0.10 & 0.09 & 0.06 \\
\hline $\mathrm{Al} 2 \mathrm{O} 3$ & 13.90 & 13.80 & 11.30 & 14.80 & 11.90 & 10.80 & 13.70 \\
\hline $\mathrm{Fe} 2 \mathrm{O} 3$ & 1.48 & 0.84 & 0.68 & 0.91 & 0.71 & 0.21 & 0.60 \\
\hline $\mathrm{MnO}$ & 0.05 & 0.05 & 0.03 & 0.06 & 0.01 & 0.01 & 0.01 \\
\hline $\mathrm{MgO}$ & 1.13 & 1.10 & 0.14 & 0.33 & 0.11 & 0.01 & 0.05 \\
\hline $\mathrm{CaO}$ & 0.49 & 0.54 & 0.36 & 0.41 & 0.74 & 0.89 & 0.34 \\
\hline $\mathrm{Na} 2 \mathrm{O}$ & 1.01 & 1.29 & 1.59 & 2.50 & 1.20 & 2.60 & 0.06 \\
\hline $\mathrm{K} 2 \mathrm{O}$ & 3.82 & 3.78 & 4.37 & 4.68 & 7.36 & 4.08 & 9.37 \\
\hline $\mathrm{P} 2 \mathrm{O} 5$ & 0.18 & 0.20 & 0.20 & 0.36 & 0.02 & 0.03 & 0.27 \\
\hline LOI & 5.56 & 5.30 & 2.90 & 2.45 & 1.58 & 1.35 & 1.29 \\
\hline Total & 99.32 & 99.36 & 99.53 & 99.46 & 99.83 & 99.88 & 99.75 \\
\hline $\mathrm{ppm}$ & & & & & & & \\
\hline $\mathrm{Cr}$ & 19 & 12 & 10 & 14 & 11 & 10 & 10 \\
\hline $\mathrm{Ni}$ & 16 & 14 & 14 & 13 & 11 & 10 & 10 \\
\hline $\mathrm{Rb}$ & 691 & 684 & 581 & 840 & 230 & 142 & 656 \\
\hline $\mathrm{Ba}$ & 256 & 94 & 134 & 42 & 357 & 296 & 583 \\
\hline $\mathrm{Ga}$ & 26 & 26 & 18 & 31 & 14 & 13 & 25 \\
\hline $\mathrm{Nb}$ & 27 & 21 & 22 & 28 & 11 & 12 & 19 \\
\hline $\mathrm{Sr}$ & 40 & 37 & 40 & 30 & 79 & 71 & 179 \\
\hline V & 10 & 10 & $<10$ & $<10$ & $<10$ & $<10$ & $<10$ \\
\hline $\mathrm{Zr}$ & 40 & 27 & 30 & 32 & 142 & 122 & 20 \\
\hline $\mathrm{Ti}$ & 635 & 348 & 360 & 354 & 593 & 564 & 348 \\
\hline $\mathrm{Zn}$ & 96 & 74 & 23 & 353 & 14 & $<10$ & 29 \\
\hline$Y$ & 22 & 13 & 22 & 12 & 16 & 16 & 7 \\
\hline $\mathrm{La}$ & 4.0 & 4.8 & 12.0 & 3.1 & 27.4 & 28.5 & 2.3 \\
\hline $\mathrm{Ce}$ & 6.7 & 9.3 & 21.0 & 5.4 & 49.9 & 51.2 & 5.0 \\
\hline $\operatorname{Pr}$ & 0.8 & 1.1 & 3.5 & 0.6 & 5.2 & 5.2 & 0.5 \\
\hline $\mathrm{Nd}$ & 3.9 & 5.0 & 14.0 & 2.6 & 21.0 & 21.1 & 2.4 \\
\hline $\mathrm{Sm}$ & 1.2 & 1.3 & 4.0 & 0.8 & 3.5 & 3.5 & 0.8 \\
\hline $\mathrm{Eu}$ & 0.4 & 0.3 & 0.9 & 0.1 & 0.6 & 0.4 & 0.1 \\
\hline $\mathrm{Gd}$ & 1.8 & 1.3 & 3.6 & 0.7 & 3.1 & 2.8 & 1.0 \\
\hline $\mathrm{Tb}$ & 0.3 & 0.2 & 0.7 & 0.2 & 0.5 & 0.5 & 0.1 \\
\hline Dy & 2.1 & 1.1 & 2.9 & 0.8 & 2.9 & 2.7 & 1.3 \\
\hline $\mathrm{Ho}$ & 0.4 & 0.2 & 0.5 & 0.1 & 0.6 & 0.6 & 0.2 \\
\hline $\mathrm{Er}$ & 1.0 & 0.5 & 1.1 & 0.3 & 1.8 & 1.7 & 0.6 \\
\hline $\mathrm{Tm}$ & 0.2 & 0.1 & 0.2 & 0.1 & 0.3 & 0.3 & 0.1 \\
\hline $\mathrm{Yb}$ & 0.9 & 0.4 & 0.8 & 0.3 & 2.0 & 1.8 & 0.6 \\
\hline $\mathrm{Lu}$ & 0.1 & 0.1 & 0.1 & 0.0 & 0.3 & 0.3 & 0.1 \\
\hline$(\mathrm{La} / \mathrm{Yb}) \mathrm{N}$ & 2.92 & 7.41 & 9.82 & 7.26 & 9.53 & 10.61 & 2.62 \\
\hline (Tb/Yb)N & 1.49 & 2.23 & 3.49 & 2.31 & 1.19 & 1.12 & 1.11 \\
\hline$(\mathrm{La} / \mathrm{Sm}) \mathrm{N}$ & 2.08 & 2.31 & 1.87 & 2.51 & 4.83 & 5.09 & 1.75 \\
\hline $\mathrm{K} / \mathrm{Rb}$ & 45.89 & 45.88 & 62.44 & 46.25 & 265.65 & 238.52 & 118.57 \\
\hline $\mathrm{Eu} / \mathrm{Eu}^{*}$ & 0.73 & 0.68 & 0.72 & 0.37 & 0.53 & 0.40 & 0.17 \\
\hline $\mathrm{Zr} / \mathrm{Nb}$ & 1.48 & 1.29 & 1.36 & 1.14 & 12.91 & 10.17 & 1.05 \\
\hline $\mathrm{Zr} / \mathrm{Y}$ & 1.82 & 2.08 & 1.36 & 2.67 & 8.88 & 7.63 & 3.08 \\
\hline
\end{tabular}

Table I. Major (wt\%) and trace (ppm) element compositions of the studied rhyolites from Zitouna (RZ), Ain Barbar (AB) and Chetaibi $(\mathrm{C})$ areas. 
After recalculating data to $100 \%$ on an $\mathrm{H}_{2} \mathrm{O}$ - and $\mathrm{CO}_{2}$-free basis, all samples are plotted in the rhyolite field in the TAS diagram of Le Maitre (1989) (Fig. 4). However the studied rocks have undergone weathering and hydrothermal alteration, especially in Ain Barbar, where alkalis have been remobilized (Marignac, 1985). Thus, in order to precise the classification of these rocks, a diagram with relatively immobile elements $\mathrm{Ti}$ and $\mathrm{Zr}$ has been used (Fig. 5A) (Winchester and Floyd, 1977). We have also used the $\mathrm{Nb} / \mathrm{Y} \& \mathrm{Zr} / \mathrm{TiO}_{2}$ diagram (Fig. 5B) because the rhyolites are also affected by secondary silicification. According to this diagram, the Zitouna and Ain Barbar rocks correspond to trachy-andesites whereas the Chetaibi rocks are rhyolites.

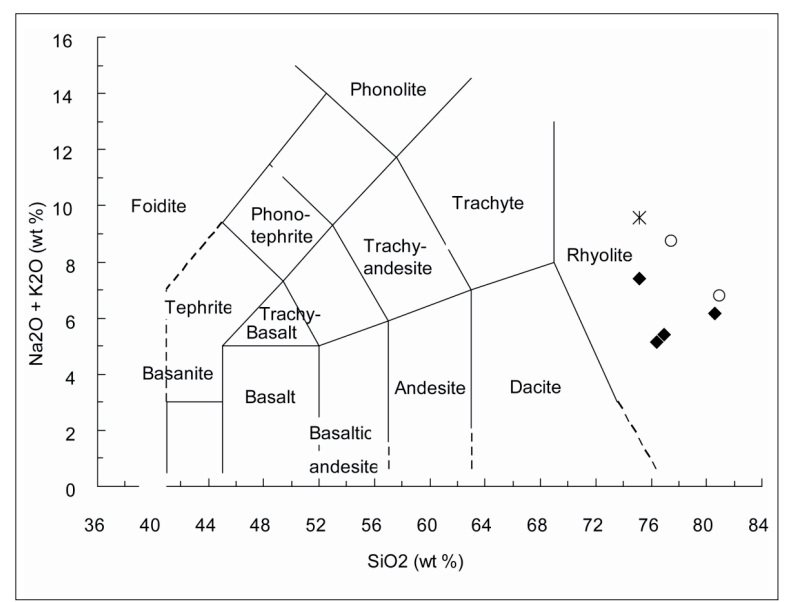

Figure 4. Total alkalis versus silica diagram showing the data plotted within the compositional field of rhyolite (Le Maitre, 1989). Rhombus: Zitouna rhyolites, circles: Chetaibi rhyolites, asteriscs: Ain Barbar rhyolites.
The values shown in the diagram $\mathrm{A} / \mathrm{CNK} \& \mathrm{Al}_{2} \mathrm{O} /$ $\left(\mathrm{CaO}+\mathrm{Na}_{2} \mathrm{O}+\mathrm{K}_{2} \mathrm{O}\right)$ are computed in molar proportions in order to be able to compare the different rhyolites (Fig. 6). In the Zitouna rhyolite, the results range from 1.41 to 2.08 and indicate a high to very high peraluminous character, as in the Ain Barbar rhyolite (1.26). However the Chetaibi rhyolites have lower A/CNK (1.05-1.06). The A/CNK versus A/NK diagram also defines the rocks as peraluminous (Maniar and Piccolli, 1989). As samples have undergone an important hydrothermal alteration, this high peraluminosity must be evaluated in relation to the hydrothermal alteration through the AI-CCPI diagram (Fig. 7A) (Gifkins et al., 2005). AI is known as Ishikawa alteration index and ASI corresponds to aluminium saturation index, also named as A/

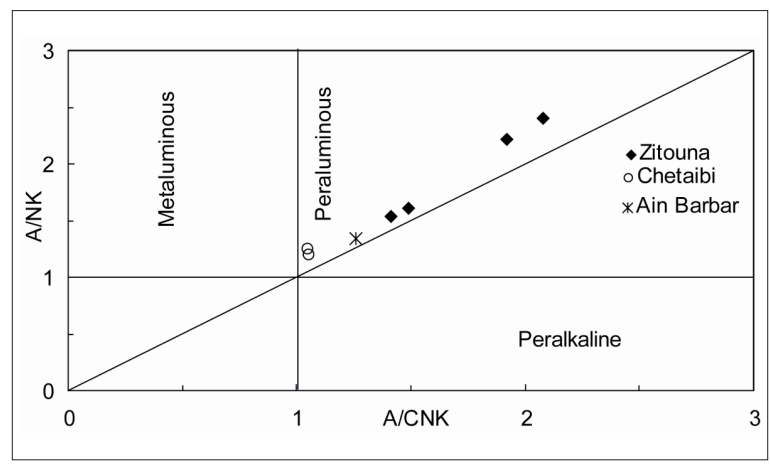

Figure 6. Location of the studied rhyolites composition in the classification diagram of molar ratios of $\mathrm{A} / \mathrm{CNK}\left(\mathrm{Al}_{2} \mathrm{O}_{3} /\right.$ $\left.\left(\mathrm{CaO}+\mathrm{Na}_{2} \mathrm{O}+\mathrm{K}_{2} \mathrm{O}\right)\right)$ versus $\mathrm{A} / \mathrm{NK}\left(\mathrm{Al}_{2} \mathrm{O}_{3} /\left(\mathrm{Na}_{2} \mathrm{O}+\mathrm{K}_{2} \mathrm{O}\right)\right)(\mathrm{Ma}-$ niar and Piccolli, 1989). Symbols as in figure 4. The abbreviations are explained in the text.
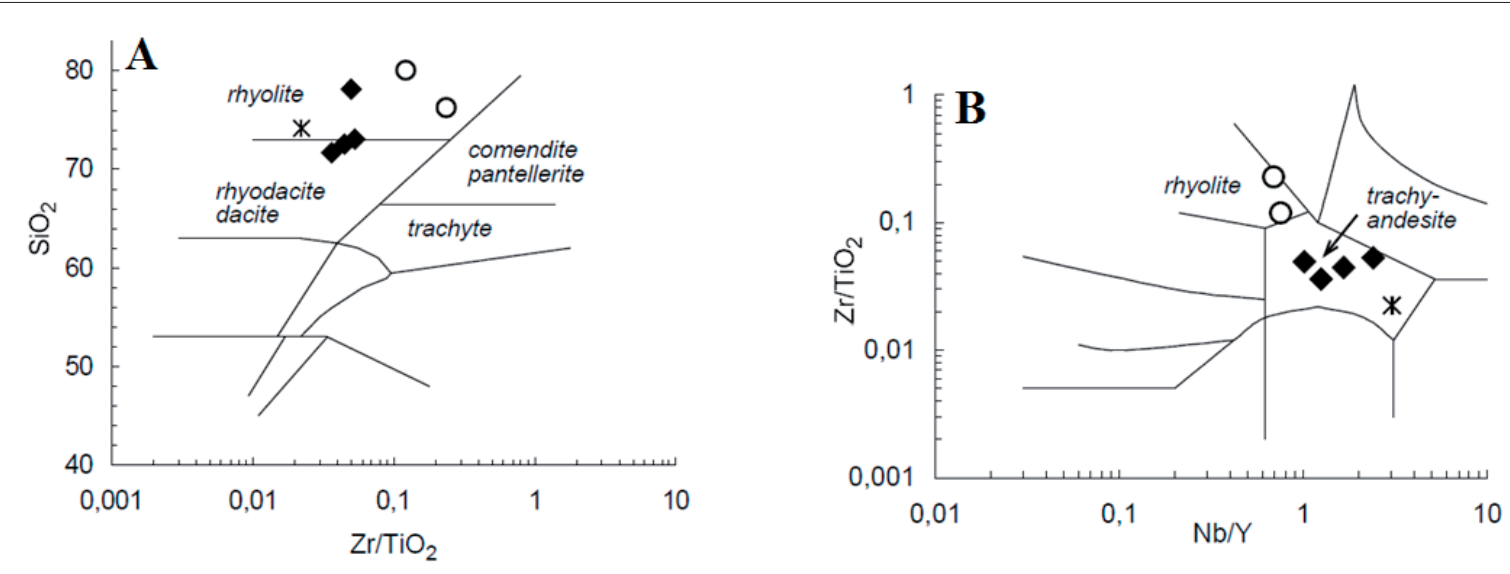

Figure 5. Rock classification using immobile trace elements (Winchester and Floyd, 1977). A) $\mathrm{Zr}_{\mathrm{riO}} \mathrm{TiO}_{2}$ and $\mathrm{SiO}_{2}$. B) $\mathrm{Nb} / \mathrm{Y}$ and $\mathrm{Zr} /$ $\mathrm{TiO}_{2}$. Symbols as in figure 4. 
CNK. Both AI $\left(100 *\left(\mathrm{MgO}+\mathrm{K}_{2} \mathrm{O}\right) / \mathrm{MgO}+\mathrm{K}_{2} \mathrm{O}+-\right.$ $\left.\mathrm{CaO}+\mathrm{Na}_{2} \mathrm{O}\right)$ and CCPI $(100 *(\mathrm{FeO}+\mathrm{MgO}) /$ $\left.\mathrm{FeO}+\mathrm{MgO}+\mathrm{Na}_{2} \mathrm{O}+\mathrm{K}_{2} \mathrm{O}\right)$ are expressed in molar proportions in figure $7 \mathrm{~A}$. The Zitouna rhyolite is not very separated from the less altered rocks

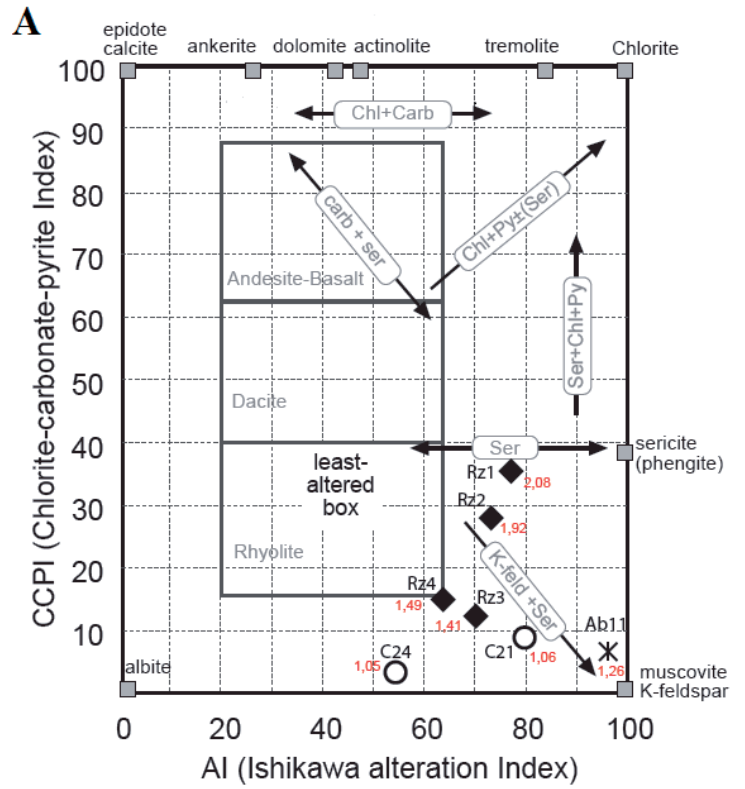

B

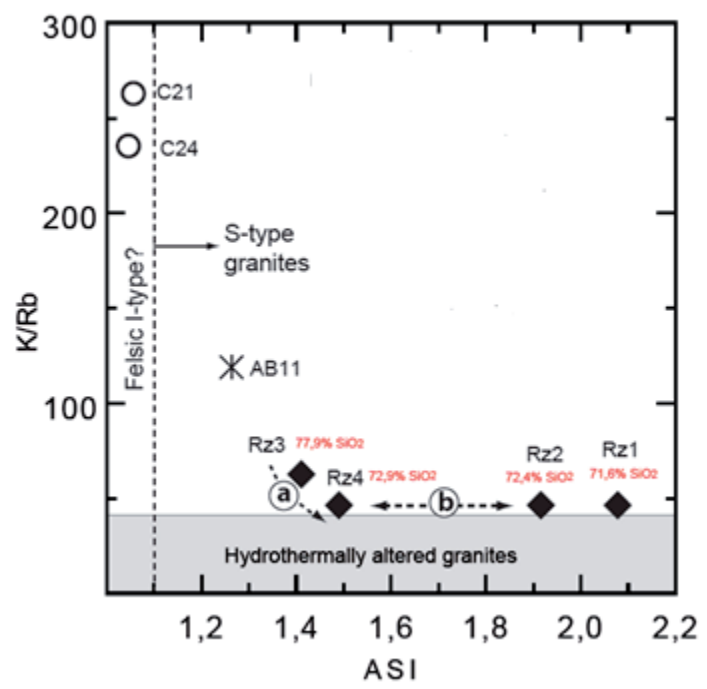

Figure 7. Evaluation of hydrothermal alteration and magma type. A) Hydrothermal alteration trends of studied rhyolites in AI versus CCPI expressed in molar proportions (Gifkins et al., 2005). AI: $100\left(\mathrm{MgO}+\mathrm{K}_{2} \mathrm{O}\right) / \mathrm{MgO}+\mathrm{K}_{2} \mathrm{O}+\mathrm{CaO}+\mathrm{Na}_{2} \mathrm{O}$; CCPI: $100(\mathrm{FeO}+\mathrm{MgO}) / \mathrm{FeO}+\mathrm{MgO}+\mathrm{Na}_{2} \mathrm{O}+\mathrm{K}_{2} \mathrm{O} . \mathrm{A} / \mathrm{CNK}$ values are represented in red color. $\mathrm{B}$ ) Decreasing/increasing trend of the studied rhyolites in the ASI versus $\mathrm{K} / \mathrm{Rb}$ diagram (altered granites, $\mathrm{K} / \mathrm{Rb}=30-40$, after Muecke and Clarke, 1981). Symbols as in figure 4 . The abbreviations are explained in the text. and there is no correlation between the increase in AI and ASI. Samples with high Al index from Chetaibi and Ain Barbar have lower ASI than the Zitouna rhyolite.

According to Muecke and Clarke (1981) hydrothermally altered granites have $\mathrm{K} / \mathrm{Rb}=30-40$ (Fig. $7 \mathrm{~B})$. In the ASI \& $\mathrm{K} / \mathrm{Rb}$ diagram, the Zitouna rhyolite describes a trend of increase/decrease of ASI without variation in the $\mathrm{K} / \mathrm{Rb}$ ratio, coinciding with the dashed path (b). The tendency described in (a) reflects a small K/Rb decrease and ASI increase, presumably due to slight late-magmatic hydrothermal alteration.

The low Sr contents (30-40 ppm) are linked to modest $\mathrm{CaO}$ values and also confirm plagioclase depletion. The high $\mathrm{Rb}$ contents (581-840 ppm) are following the $\mathrm{K}$ behaviour. $\mathrm{Ba}$ is variable (42$256 \mathrm{ppm}$ ) which may be due to alteration. When compared to average values of crustal material, the $\mathrm{Sr}(30-40 \mathrm{ppm})$ and $\mathrm{Ba}(42-256 \mathrm{ppm})$ contents are lower, whereas the $\mathrm{Rb}$ (581-840 ppm) is much higher in the Zitouna rhyolite than the values given by Rudnick and Fountain (1995) which are: Sr (325 ppm), Ba (390 ppm), Rb (58 ppm ). K/Rb ratios (46 to 62). The Ain barbar rhyolite shows the highest $\mathrm{Sr}$ (179 ppm) and $\mathrm{Ba}(583 \mathrm{ppm})$ contents, but its $\mathrm{K} /$ $\mathrm{Rb}$ ratio is intermediate between those from Zitouna and Chetaibi (119 ppm). The Chetaibi rhyolite appears to be different to the Zitouna rhyolite; it has higher contents in Sr (71-79 ppm), Ba (296-357 $\mathrm{ppm})$ and $\mathrm{K} / \mathrm{Rb}(239-266)$ and a very lower contents in $\mathrm{Rb}$ (142-230 ppm).

In order to evaluate melt-generating processes, the chemical compositions of studied rhyolite were normalized to chondrite (Fig. 8A). The normalizing values were taken by Sun and McDonough (1989). The Zitouna rhyolite normalized to chondrite shows negative $\mathrm{Ti}, \mathrm{Ba}, \mathrm{Sr}$ and $\mathrm{P}$ anomalies compared to their neighboring elements. The negative anomaly in $\mathrm{P}$ is indicative for low content of apatite in the studied rocks. The negative anomalies of $\mathrm{Ti}$ are controlled by titanium bearing minerals such as titanite or ilmenite. However the $\mathrm{Nb}$ negative anomaly, typical of orogenic environment, is quiet moderate. There is a noticeable difference in the $\mathrm{P}$ negative anomalies, while $\mathrm{Ti}$ anomalies are similar in all rhyolites. 
The Zitouna rhyolite has low REE contents; the total of analysed elements varies between 15 and 70 $\mathrm{ppm}$. The $(\mathrm{La} / \mathrm{Yb})_{\mathrm{n}}$ varies from 3 to 9 . The chondrite normalized REE patterns display a slight slope from light to heavy rare earth elements and a small but persistent negative europium anomaly $\left(\mathrm{Eu} / \mathrm{Eu}^{*}\right.$ from 0.37 to 0.73 ) (Fig. 8B) (Nakamura, 1974). The Eu/ $\mathrm{Eu}^{*}$ negative anomaly is similar in rocks with higher (77.9\%) and lower (71.6-72.4\%) $\mathrm{SiO}_{2}$ contents, in disagreement with plagioclase fractionation in the rhyolitic melt. The Chetaibi rhyolites show different normalized patterns with higher content of $\mathrm{Ba}, \mathrm{La}$, $\mathrm{Ce}, \mathrm{Pr}, \mathrm{Sr}, \mathrm{Nd}, \mathrm{Zr}$, some HREE, and lower $\mathrm{Rb}, \mathrm{Nb}$, P. They have a higher content of REE, higher LREE fractionation, and flat HREE patterns, in relation to the Zitouna and Air Barbar rhyolites.
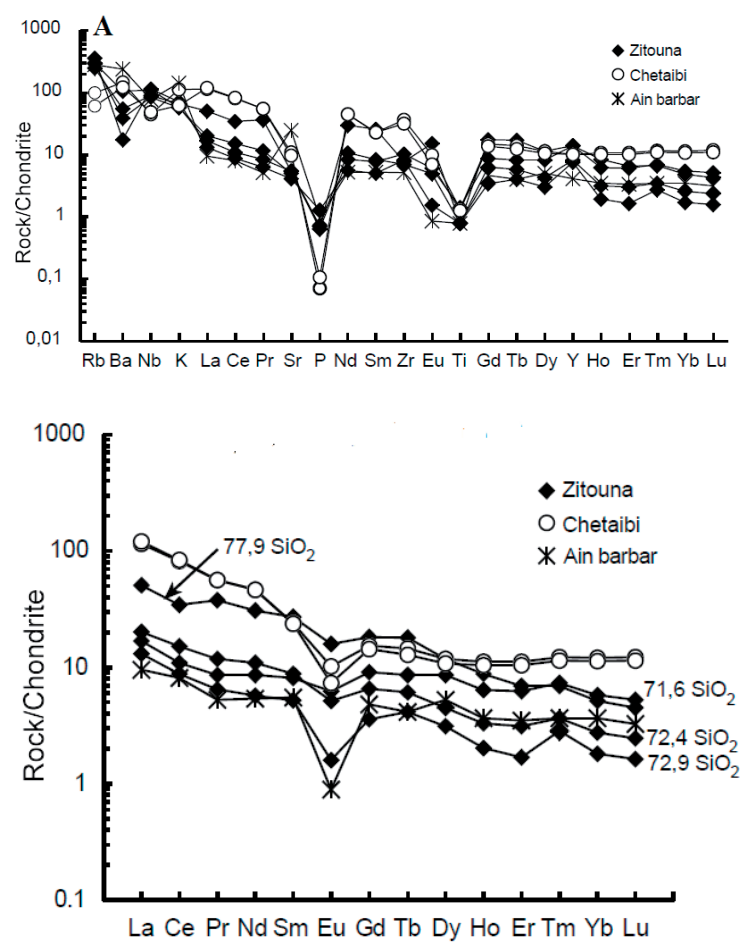

Figure 8. A) Chondrite normalized trace element abundances for representative samples from Zitouna, Ain Barbar and Chetaibi. Normalizing values are taken from Sun and $\mathrm{McD}$ Donough (1989), and B) Chondrite normalized REE abundance patterns for representative samples from Zitouna, Ain Barbar and Chetaibi. Normalizing values are taken from Nakamura (1974).

\section{Discussion}

Numerous outcrops of igneous rocks, especially acidic rocks, have been recognized in the widespread area of northeast Algeria. When compared to northwest Annaba rhyolites, the Zitouna rhyolite shows many differences. Thus, the Zitouna rhyolite is not accompanied by other igneous rocks and it is younger (less than $12 \mathrm{Ma}$ ) than other acidic rocks of northwest Annaba. The A/ASI ratios reveal that the peraluminous character is very pronounced in the Zitouna rhyolite and much less pronounced in the Ain Barbar and Chetaibi rhyolites (Figs. 6 and $7 \mathrm{~A}$ and $7 \mathrm{~B})$.

Figure 9 illustrates several diagrams used to decipher the nature of the magma source (Pearce et al., 1984). In the $\mathrm{Y}+\mathrm{Nb} \& \mathrm{Rb}$ diagram (Fig. 9C) the Zitouna and Ain Barbar rhyolites are plotted in the syn-collisional setting, whereas the Chetaibi rhyolite plots in the volcanic-arc setting. The particularities related to the structural position of the studied rhyolites are important as well. Thus, the Zitouna area is located in a higher structural level and more external than northwest Annaba and this may explain the lack of some structural units (Mauritanian and Massylian flysch, dorsal, metamorphic basement).

Geothermal and magnetic anomalies are more significant in the study area than elsewhere in northeast Algeria (Fig. 10). Northeast Algeria is characterized by a relatively high geothermal gradient $\left(5^{\circ} / 100 \mathrm{~m}\right.$ on average) due to lithospheric thinning (Kazi-Tani, 1986). 100 to $290 \mathrm{~m}$ depth wells located less than $10 \mathrm{~km}$ away from Zitouna at the Algerian-Tunisian border show temperatures above average $\left(1^{\circ} / 30 \mathrm{~m}\right)$, exceeding in some cases $1 \% 10 \mathrm{~m}$. At surface, this geothermal anomaly is revealed by several thermal springs or "hammams" (Mexa, Sidi Trad, Beni Salah and Meskhoutine), where water temperature ranges from $30^{\circ}$ to $95^{\circ} \mathrm{C}$. Data from the Geotravers Programm carried out in Tunisia corroborate the crustal thinning and the shallow depth of the Moho (25 km) (Mickus and Jallouli, 1999).

The Zitouna outcrops are underlined by a NW-SE trending magnetic anomaly that has been interpreted as a result of a structural-magmatic phase of distension allowing the magma ascent (Fig. 11) (Vila, 


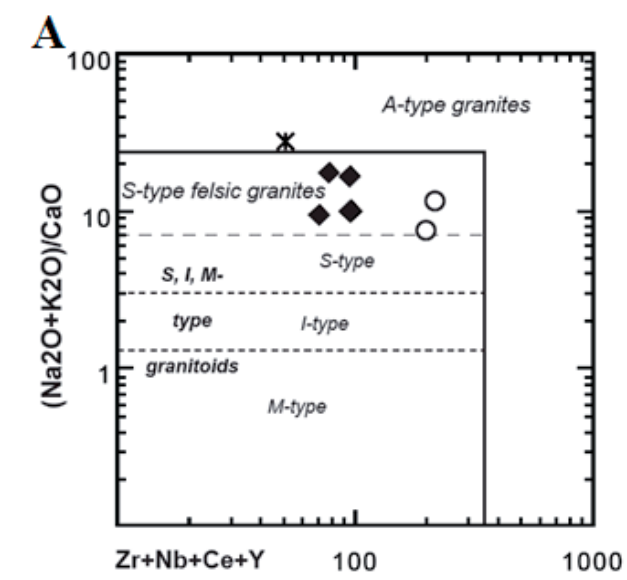

B

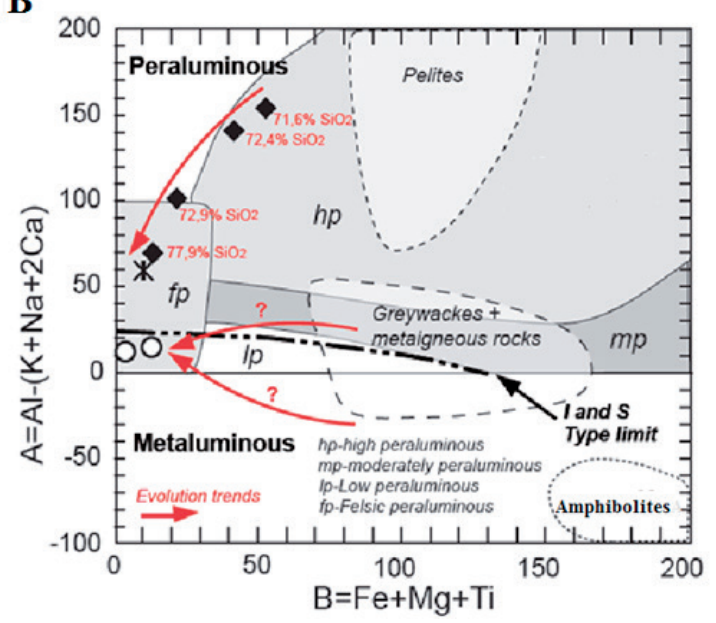

C

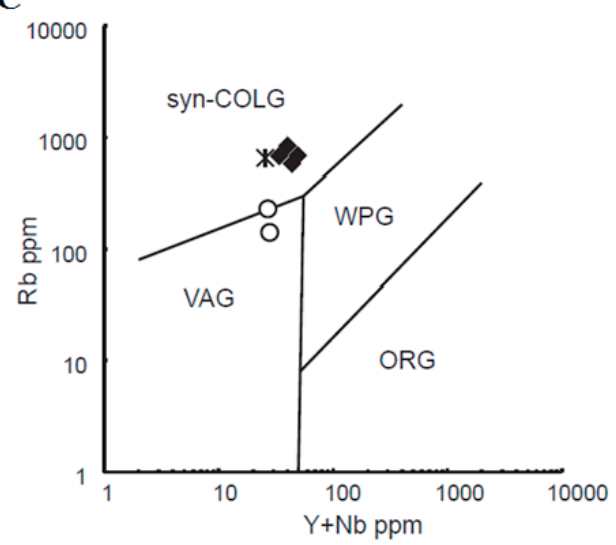

Figure 9. A) Position of studied rhyolites composition in the $\mathrm{Zr}+\mathrm{N}-$ $\mathrm{b}+\mathrm{Ce}+\mathrm{Y}$ versus $\left(\mathrm{Na}_{2} \mathrm{O}+\mathrm{K}_{2} \mathrm{O}\right) / \mathrm{CaO}$ diagram (Whalen et al., 1987). B) Position of studied rhyolites composition in the A-B diagram (Villaseca et al., 1997, modified from Debon and Le Fort, 1983). $\mathrm{A}=\mathrm{Al}-(\mathrm{K}+\mathrm{Na}+2 \mathrm{Ca}), \mathrm{B}=\mathrm{Fe}+\mathrm{Mg}+\mathrm{Ti} . \mathrm{C})$ Location of chemical compositions of the studied rhyolites in the $\mathrm{Y}+\mathrm{Nb}$ versus $\mathrm{Rb}$ discrimination diagram from Pearce et al. (1984). Abbreviations: oceanridge granitoids (ORG); syn-collisional granitoids (SYN-COLG); volcanic-arc granitoids (VAG); within plate granitoids (WPG). Symbols as in figure 4 . The abbreviations are explained in the text.
1980). This tectono-thermal phase also coincides with the Numidian emplacement and an explosive and intrusive magmatic activity documented throughout the Western Mediterranean (e. g., Bellon, 1976). A narrow relationship seems to occur between various magmatic events and successive tectonic phases since the Early Eocene to Upper Miocene in this region. In addition to the geotectonic evolution, a change in the magmatism nature has been documented (Talbi et al., 2005). We propose

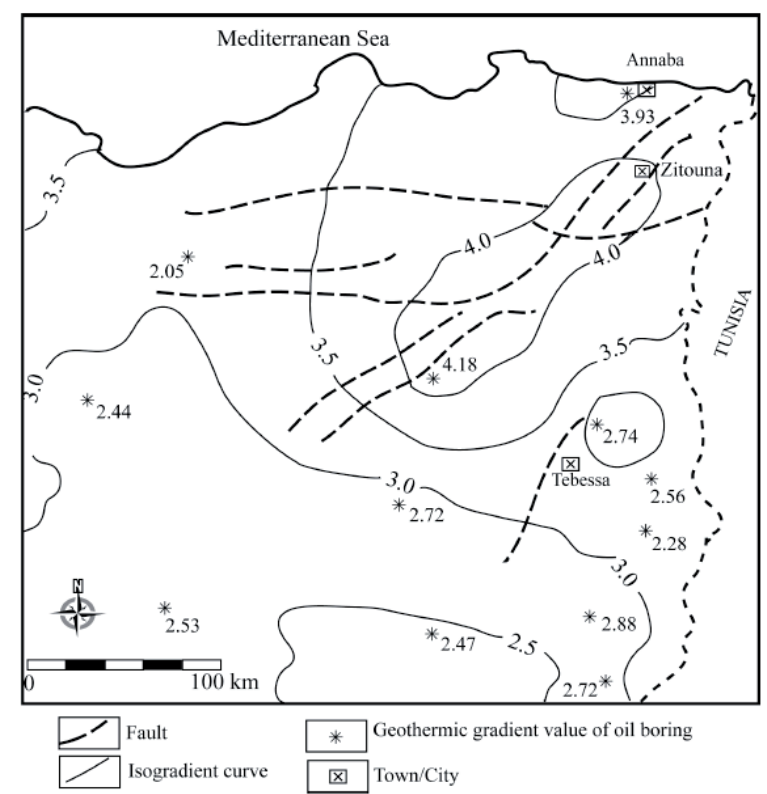

Figure 10. Sketch map of northeast Algeria showing geothermal gradients (modified after Bouchareb et al., 1993).

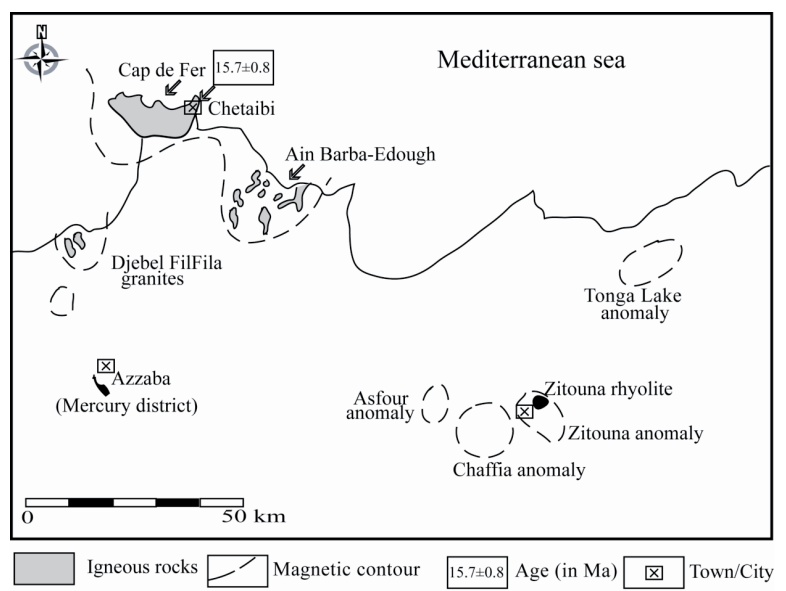

Figure 11. Sketch map of north Algeria with different magnetic anomalies and igneous rock outcrops (modified after Vila, 1980). 
that the Zitouna magmatism may be related to the end of the Kabylie-Africa collision during the Atlasic phase.

The rhyolitic intrusions are probably the superficial evidence of a semi-deep magma chamber revealed by geothermal and magnetic anomalies, as well as by hydrothermal alteration and mineralization. The magmatic activity has also metallogenic implications in the region; in addition to several occurrences, the ore deposit of Kef Oum Teboul corresponds to a polymetallic mineralization $(\mathrm{Cu}, \mathrm{Pb}, \mathrm{Zn}, \mathrm{Hg}, \mathrm{Sb})$ forming veins that intrude the Numidian flysch. The hydrothermal activity that accompanied or followed the different igneous events induced the remobilization and concentration of chemical elements. Thus, sulphide mineralizations located within sedimentary rocks are considered as magmatogenic.

\section{Conclusions}

The age of the Zitouna rhyolite is post-Serravallian (not older than $12 \mathrm{Ma}$ ) and constitutes the easternmost outcrop of Neogene magmatic rocks in northeast Algeria. Geochemical data show that this rhyolite belongs to S-type granites with a high peraluminous character corroborating a crustal origin.

A comparison with the Ain Barbar and Chetaibi rhyolites shows that the peraluminous character is lesser at Ain Barbar and slightly lesser at Chetaibi. The Ain Barbar rhyolite also derives from a crustal source and its geochemical composition is often intermediate between those from Chetaibi and $\mathrm{Zi}$ touna. Considering the geological context (presence of basic rocks) and the geochemical features, only the Chetaibi rhyolite could represent a felsic I-type source.

The Zitouna rhyolite is a late magmatic expression related to the Neogene geodynamic evolution of the northeast African margin. The successive tectonic phases, particularly during the Atlasic distensive stage, may have favoured the rise of magmas derived from crustal melting.

\section{Acknowledgements}

We are greatly indebted to Gloria Gallastegui for the valuable helpful suggestions that improved significantly this study. An anonymous reviewer is sincerely acknowledged for the constructive criticisms and comments. The authors also thank C. Físcher, A Musiol and C. Günter from Potsdam University as well as D. Rhede and O. Appelt for their support in sample preparation and analytical laboratories.

\section{References}

Bagdazarjan, G. P., Bajanic, S. D. and Vass, D. (1972): Age radiométrique du volcanisme néogène dans le nord de la Tunisie. Notes Service Géologique de Tunisie, 40: 79-93.

Bellon, H. (1976): Séries magmatiques néogènes et quaternaires du pourtour de la Méditerranée Occidentale, comparées dans leur cadre géochronologique; implications géodynamiques. Thèse d'Etat, Université d'Orsay, 367 p.

Bouchareb, H., Haouchini, F. Z., Issadi, A. and Bendia, A. (1993): Estimation et interprétation du gradient géothermique en Algérie du Nord. Bulletin du Service Géologique d'Algérie, 5 (2): 69-74.

Bouillin, J. P. (1986): Le "bassin maghrébin": une limite entre l'Europe et l'Afrique à l'ouest des Alpes. Bulletin de la Société Géologique de France, 2(4): 547-558.

Debon, F. and Le Fort, P. (1983): A chemical-mineralogical classification of common plutonic rock and associations. Transactions of the Royal Society of Edinburgh: Earth Sciences, 73: 135-149.

Dulski, P. (1994): Interferences of oxide, hydroxide and chloride analyte species in the determination of rare earth elements in geological samples by inductively coupled plasma-mass spectrometry. Fresenius' Journal of Analytical Chemistry, 350(4): 194-203. 
Durand-Delga, M. (1980): La Méditerranée occidentale: étape de sa genèse et problèmes structuraux liés à celle-ci. Mémoire de la Société Géologique de France, 10: 203-224.

Fougnot, J. (1990): Le magmatisme Miocène du littoral Nord-Constantinois (Algérie). Caractères, origine, signification. Thèse de Doctorat, Université de Nancy.

Gélard, J. P. (1969): Géologie du nord-est de la Grande Kabylie (un segment des zones internes de l'orogène littoral maghrebin). Thèse des sciences Université de Dijon, 305 p.

Gifkins, C., Herrmann, W. and Large, R. (2005): Altered volcanic rocks. A guide to description and interpretation. Published by Centre for Ore Deposit Research. University of Tasmania, Australia, $271 \mathrm{p}$.

Hilly, J. and Rast, A. (1954): Découverte d'un pointement rhyolitique dans l'extrême Est constantinois (Algérie). Bulletin de la Société d'Histoire Naturelle d'Afrique du Nord, 45: 35-38.

Hilly, J. (1962): Etude géologique du Massif de l'Edough et du Cap de Fer (EstConstantinois), Bulletin du Service de la Carte Géologique d'Algérie, Nouvelle Série, 19.

KAZI-TANI, N. (1986): Evolution géodynamique de la bordure nord algérienne: un domaine intraplaque nord algérien, approche mégaséquentielle. Thèse d'Etat, Uniersité de Pau, 800 p.

Laouar, R., Boyce, A. J., Arafa, M., Ouabadi, A. and Fallick, A. E. (2005): Petrological, geochemical and stable isotope constraints on the genesis of the Miocene igneous rocks of Chetaibi and Cap de Fer (NE Algeria). Journal of African Earth Sciences, 41(5): 21.

Le Maitre, R. W. (1989): A classification of igneous rocks and glossary of terms: Recommendations of the International Union of Geological Sciences. Subcommission on systematics of igneous rocks. Blackwell, Oxford, 193 p.
Maniar, P. D. and Piccolli, P. M. (1989): Tectonic discrimination of granitoids. GSA Bulletin, 101: 635-643.

MARIGNAC, C. (1985): Les minéralisations filoniennes d'Ain Barbar (Algérie). Un exemple d'hydrothermalisme lié à l'activité géothermique alpine en Afrique du Nord. Thèse de Doctorat. Université de Lorraine, Nancy.

Maury C., Fourcade, S., Coulon, C., El Azzouzid, M., Bellon, H., Coutelle, A., Ouabadi, A., Semroud, B., Megartsi, M., Сotton, J., Belanteur, O., Louni-Hacini, A., Piqué, A., Capdevila, R., Hernandez, J. and Réhault, J. P. (2000): Post-collisional Neogene magmatism of the Mediterranean Maghreb margin: a consequence of slab breakoff. Comptes Rendus de l'Académie des Sciences, 331: 159-173.

Mickus, K. and Jallouli, C. (1999): Crustal structure beneath the Tell and Atlas Moutains (Algeria and Tunisia) through the analysis of gravity data. Tectonophysics, 314: 373-385.

Muecke, G. K. and Clarke, D. B. (1981): Geochemical evolution of the Routh mountain batholith, Nova Scotia: Rare Earth-Element evidence. Canadian Mineralogist, 19: 133-145.

Nakamura, N. (1974): Determination of REE, Ba, $\mathrm{Fe}, \mathrm{Mg}, \mathrm{Na}$ and $\mathrm{K}$ in carbonaceous and ordinary chondrites. Geochimica et Cosmochimica Acta, 38 (5): 757-775.

Pearce, J. A., Harris, N. B. W. and Tindle, A. G. (1984): Trace elements discriminations diagrams for the tectonic interpretations of granitic rocks. Journal of Petrology, 2: 956- 983.

Raoult, J. F. (1974): Géologie de la chaîne Numidique (Nord du constantinois-Algérie). Mémoires de la Société Géologique de France, 12: $163 \mathrm{pp}$.

Raoult, J. F and Velde, D. (1971): Découverte de trachytes potassiques à olivine d'andésites en coulées dans le Miocène continental au sud. Les trachytes du Kef Haouner (Nord du constanti- 
nois). Comptes Rendus de l'Académie des Sciences, 272: 1051-1059.

Rudnick, R. and Fountain, D. M. (1995): Nature and composition of the continental crust: A lower crustal perspective. Review of Geophysics, 33 (3): 267-309.

Sun, S. S. and McDonough, W. F. (1989): Chemical and isotopic systematic of oceanic basalts: implications for mantle composition and processes. In: Saunders, A. D. and Norry M. J. (editors), Magmatism and Ocean Basins. Geological Society, Special Publications, 42: 313-345.

Talbi, F, JaAfari, M. and Tlig, S. (2005): Magmatisme néogène de la Tunisie septentrionale : pétrogenèse et événements géodynamiques; $R e$ vista de la Sociedad Geologica de España, 18: 241252.

Talbi, F., Melki. F., Ben Ismail-Lattrache, R., Alouani, S. and Tlig, S. (2008): Le Numidi- en de la Tunisie septentrional: données stratigraphiques et interprétation géodynamique. Estudios Geológicos, 64: 31-44.

VILA, J. M. (1980): La chaîne alpine de l'Algérie orientale et des confins algéro-tunisiens. Thèse de Doctorat, Université de Paris, 663 p.

Villaseca, C., Barbero, L. and Herreros, V. (1988): A reexamination of the typology of peraluminous granite types in intracontinental orogenic belts. Transactions of the Royal Society of Edinburgh. Earth Sciences, 89: 113-119.

Whalen, J. B., Currie, K. L. and Chappell, B. W., (1987): S-type granites: geochemical characteristics, discrimination and petrogenesis. Contributions to Mineralogy and Petrology, 95: 407-419.

Winchester, J. H. and Floyd, P. A. (1977): Geochemical discrimination of different magma series and their differentiation products using immobile elements. Chemical Geology, 20: 325-343. 